\title{
Seasonal and tidal abundance of crab larvae in a tropical mangrove system, Gulf of Nicoya, Costa Rica
}

\author{
A. I. Dittel, C. E. Epifanio \\ College of Marine Studies, University of Delaware, Lewes, Delaware 19958, USA
}

\begin{abstract}
Crab larvae were collected from a platform moored in the mouth of a mangrove estero (= tidal creek) in the Gulf of Nicoya on the Pacific coast of Costa Rica, Central America. Eight observation periods encompassed both spring and neap tides and covered all seasons of the year. During each observation period, samples were collected every $2 \mathrm{~h}$ over 5 consecutive tidal cycles. Samples were collected from a depth of $1 \mathrm{~m}$ with a gasoline-powered impeller pump; total volume of each sample was 10 to $12 \mathrm{~m}^{3}$. The gross taxonomic composition of the observed larval assemblage was similar to that seen in temperate estuaries along the Atlantic coast of North America. Larvae of Uca spp., Grapsidae, Xanthidae and commensal crabs such as Pinnotheres spp. Were the most common. However, abundance of individual taxa was greater than that seen in temperate estuaries with common forms in excess of 1000 larvae $\mathrm{m}^{-3}$. In contrast to temperate estuaries, spawning occurred year-round, but individual taxa showed distinct seasonality. As in temperate estuaries, spawing in the estero was also influenced by lunar cycles and larvae of several taxa showed tidally rhythmic changes in abundance. Zoea I of Uca spp., Grapsidae, Xanthidae, Pinnotheres spp. and Petrolisthes spp. Were significantly more abundant during ebb tides suggesting that these larvae were spawned in the creek and exported to the open Gulf. Advanced zoea and megalopae appeared to take advantage of nocturnal flood tides to be recruited back into the estuary. Export of early stages did not occur in all taxa. Abundance of early zoeal stages of Pinnixa spp. was not affected by tidal phase suggesting that early stages were not exported from the estero.
\end{abstract}

\section{INTRODUCTION}

While many estuarine invertebrates have evolved behavioral mechanisms that enhance retention of larvae in the estuary, others export their larvae into coastal waters where further development occurs (Epifanio 1988). Larvae of retained species appear to regulate their vertical position in the water column, thus taking advantage of tidal and subtidal motion for upstream transport (Carriker 1951, Bousfield 1955, Wood \& Hargis 1971, Sandifer 1975, Cronin \& Forward 1979, 1982, Boicourt 1982, Seliger et al. 1982). Results of extensive laboratory studies have provided detailed understanding of the behavioral foundations of these adaptations. For example, studies have shown that crab larvae may alter their vertical position in response to light intensity (Forward 1974, Sulkin 1975), salinity (Latz \& Forward 1977, O'Connor \& Epifanio 1985), pressure (KnightJones \& Qasim 1966, Naylor \& Isaac 1973, Sulkin 1975, Wheeler \& Epifanio 1978, Sulkin \& van Heukelem
1982), gravity (Sulkin 1973, Latz \& Forward 1977, Sulkin et al. 1980), and temperature (Ott \& Forward 1976, Sulkin et al. 1980). Vertical movements in response to these environmental parameters may enhance retention of larvae in the estuary (Epifanio et al. 1989). Semilunar and lunar cycles of larval release may also affect dispersal and settlement rates of larvae (Christy 1978, Zucker 1978, Saigusa \& Hidaka 1978, Bergin 1981, Saigusa 1981, Paula 1989) and may also result in landward transport of megalopae by spring tide currents (Christy 1978, 1982, 1986, DeCoursey 1981).

In exported species of crab larvae, recruitment to parental populations appears to be by immigration of megalopae and juvenile stages (Sandifer 1975, Dittel \& Epifanio 1982, Epifanio et al. 1984). Recent evidence suggests that this may be accomplished by a combination of tidally rhythmic vertical migration (Epifanio et al. 1984, Epifanio et al. 1989) and wind-driven physical transport from the adjacent continental shelf into the estuary (Goodrich et al. 1989, Little \& Epifanio 1990). 
Despite the extensive literature on recruitment and dispersal patterns of estuarine crabs, little is known about the patterns of larval abundance in tropical estuaries. There have been a few studies of the general abundance of zooplankton in tropical embayments (Youngbluth 1980, Robertson et al. 1988), but there is limited information on the seasonal occurrence of larvae or on related physical factors that affect distribution in tropical systems (Epifanio \& Dittel 1984). In this paper we present the results of an investigation of the seasonal and tidal abundance of crab larvae in a tropical mangrove system.

\section{STUDY SITE}

The Gulf of Nicoya is an embayment located on the Pacific coast of Costa Rica at $10^{\circ} \mathrm{N}, 85^{\prime} \mathrm{W}$ (Fig. 1). The upper gulf, north of Isla San Lucas, is relatively shallow and is bounded by mangrove swamps along the east-
Morales narrows as it extends farther up the mangrove forest, and wide mud flats occur adjacent to its mouth. There is limited freshwater flow into the estero during the dry season, and water from the estero floods the mangrove forest on each rising tide.

\section{MATERIAL AND METHODS}

Crab larvae were collected in 1987 from a platform moored in the mouth of Estero Morales in the deepest portion of the main channel, ca $5 \mathrm{~m}$. During each observation period, samples were collected every 2 h over 5 consecutive tidal cycles. Observation periods encompassed both spring and neap tides and covered all seasons (Table 1). Samples were taken from a depth of $1 \mathrm{~m}$ using a gasoline-powered impeller pump with its outflow filtered through a $280 \mu \mathrm{m}$ mesh plankton net. Each sample was the result of $0.5 \mathrm{~h}$ pumping that

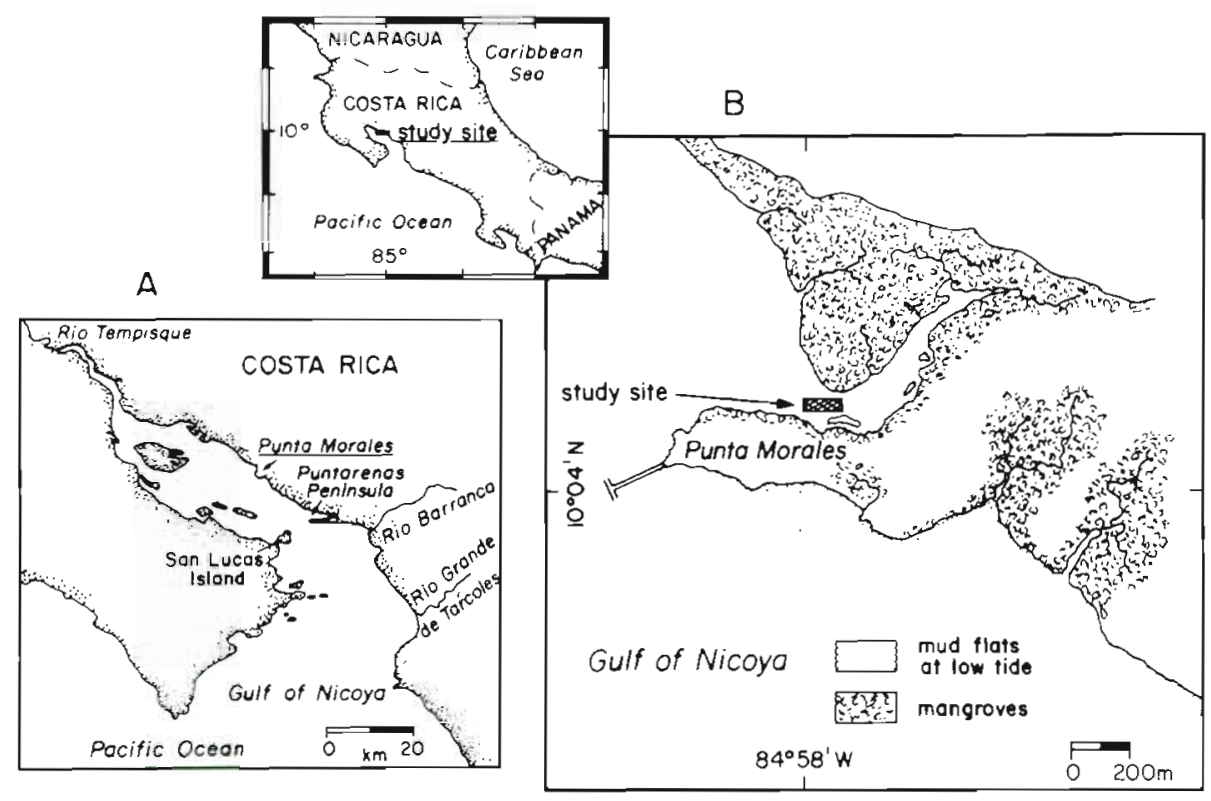

Fig. 1. Location of study site in the Gulf of Nicoya, Pacific coast of Costa Rica. (A) Gulf of Nicoya; (B) Estero Morales. (Modified from Vargas 1987)

ern and western shores. Depth in the upper gulf is generally less than $20 \mathrm{~m}$, while in the lower gulf depths are greater than $200 \mathrm{~m}$. Mean tidal range at Puntarenas is $2.3 \mathrm{~m}$, and similar tidal ranges are found throughout the upper gulf (Voorhis et al. 1983). Seasonal variation in the chemical and physical characteristics of the gulf is controlled by a rainy season from May to November and a dry season from December through April (Epifanio et al. 1983, Voorhis et al. 1983).

The study site, Estero Morales, is a tidal creek on the eastern shore of the upper gulf (Fig. 1). The estero is bordered by mangrove swamps and is characterized by a main channel ca $200 \mathrm{~m}$ wide at its mouth. Estero
Table 1. Physical parameters in surface waters in Punta Morales, Gulf of Nicoya, Costa Rica. Data are grouped by tide and seasonally; values are means

\begin{tabular}{|c|c|c|c|c|}
\hline \multirow{2}{*}{$\begin{array}{l}\text { Date } \\
(1987)\end{array}$} & \multicolumn{2}{|c|}{ Temperature $\left({ }^{\circ} \mathrm{C}\right)$} & \multicolumn{2}{|c|}{ Salinity (ppt) } \\
\hline & $\mathrm{Ebb}$ & Flood & Ebb & Flood \\
\hline $27-30 \mathrm{Jan}$ & 28.3 & 28.2 & 30.6 & 30.4 \\
\hline 9-11 Feb & 28.4 & 28.5 & 30.9 & 30.6 \\
\hline 6-8 May & 29.7 & 29.8 & 33.0 & 32.8 \\
\hline 14-16 May & 29.9 & 29.8 & 32.5 & 32.5 \\
\hline 11-13 Aug & 30.0 & 30.0 & 28.5 & 28.6 \\
\hline 18-21 Aug & 32.9 & 32.8 & 26.7 & 26.2 \\
\hline $5-7$ Nov & 29.4 & 30.0 & 24.0 & 24.2 \\
\hline
\end{tabular}


allowed the filtration of 10 to $12 \mathrm{~m}^{3}$ of water. The pump outflow was calibrated before each sampling period. Temperature and salinity at $1 \mathrm{~m}$ were measured simultaneously with each larval collection using a portable conductivity-salinity-temperature meter (YSI).

Samples were preserved immediately in $4 \%$ formaldehyde and transferred to $70 \%$ ethanol no later than 1 wk after collection. Samples were split using a Folsom splitter (Dittel \& Epifanio 1982), and one randomly chosen subsample was analyzed for each collection. Larvae were categorized by zoeal and megalopal stages and identified to family or genus. Identification was done using available keys and original descriptions (Hyman 1920, Lebour 1928, Costlow \& Bookout 1966, Costlow \& Fagetti 1967, Hasmi 1968, Knight 1968, Gore 1972, Sandifer 1972, Martin et al. 1985, Fielder \& Greenwood 1986).

Larval concentrations were transformed to $\log (x+1)$ to normalize distributions and to decorrelate the mean and variance. A Model I multifactor analysis of variance (ANOVA; $\alpha=0.05$ ) was used to test the effect of time of day, tidal stage, time of year, and lunar cycle (neap/spring tides) on the abundance of crab larvae. The F-ratio for each main effect was calculated as the mean square (MS) for that factor divided by the error mean square. Third and fourth order interactions were not analyzed because interpretation at those levels is difficult. For several taxa (Majidae, Leucosiidae and
Callinectes) 4-way ANOVA could not be used because zero-value cells occurred. Instead, 4 one-way ANOVAs were used.

\section{RESULTS}

\section{Physical data}

During the investigation, temperatures ranged from ca 28 to $33^{\circ} \mathrm{C}$, while salinities in the main channel varied from 24 to $33 \%$ (Table 2). Ebb tide salinities sometimes exceeded flood tide salinities; this suggests that evaporation and mangrove transpiration were high in the region upstream from our study site. Monthly precipitation during the rainy season ranged from 100 to $340 \mathrm{~mm}$ with peaks in July and September,

Table 2. Lunar and seasonal characterization of 1987 observation periods in Punta Morales, Gulf of Nicoya, Costa Rica

\begin{tabular}{|lll|}
\hline Observation period & Lunar phase & Annual season \\
\hline 26-28 Jan & Spring & Dry \\
9-11 Feb & Neap & Dry \\
6-8 May & Neap & Transition \\
14-16 May & Spring & Transition \\
11-13 Aug & Spring & Rainy \\
19-21 Aug & Neap & Rainy \\
5-7 Nov & Spring & Transition \\
30 Nov-2 Dec & Neap & Dry \\
\hline
\end{tabular}

Table 3. Overall composition, abundance and \% abundance of all taxa and \% frequency of occurrence of brachuyran crab larvae in Punta Morales, Gulf of Nicoya, 1987. --: the particular stage is not present in that taxon

\begin{tabular}{|c|c|c|c|c|c|c|c|c|c|c|}
\hline Taxon & ZI & ZII & ZIII & ZIV & ZV & Meg. & Juv. & Total & $\%$ & $\%$ Freq. \\
\hline \multicolumn{11}{|l|}{ Ocypodidae } \\
\hline UCa spp. & 352006 & 1756 & 399 & 190 & 192 & 9056 & 0 & 363599 & 43.0 & 99 \\
\hline Unidentified & 4432 & 0 & 0 & 4 & 0 & 0 & 12 & 4448 & 0.5 & 11 \\
\hline Grapsidae & 241661 & 79 & 22 & 29 & -- & 944 & 0 & 242735 & 28.7 & 87 \\
\hline \multicolumn{11}{|l|}{ Pinnotheridae } \\
\hline Pinnotheres spp. & 95019 & 6697 & 4949 & 4024 & 1139 & 1312 & 594 & 113734 & 13.5 & 99 \\
\hline Pinnixa spp. & 3422 & 288 & 93 & 44 & 76 & 1399 & 774 & 6096 & 0.7 & 74 \\
\hline Xanthidae & 72427 & 2544 & 791 & 204 & -- & 2622 & 33 & 78621 & 9.3 & 99 \\
\hline \multicolumn{11}{|l|}{ Porcellanidae } \\
\hline Petrolisthes spp. & 16462 & 85 & -- & -- & -- & 463 & 407 & 17417 & 2.1 & 88 \\
\hline Paguridae & 6 & 0 & 0 & 0 & 0 & 0 & 1110 & 1116 & 0.1 & 27 \\
\hline \multicolumn{11}{|l|}{ Portunidae } \\
\hline Callinectes spp. & 320 & 0 & 0 & 0 & 0 & 4 & 0 & 324 & $<0.1$ & 16 \\
\hline Majidae & 289 & 7 & -- & -- & -- & 23 & 0 & 319 & $<0.1$ & 28 \\
\hline Leucosiddae & 297 & 7 & 1 & 7 & 0 & 0 & 0 & 312 & $<0.1$ & 21 \\
\hline Raninidae & 0 & 0 & 0 & 0 & 0 & 29 & 0 & 29 & $<0.1$ & 4 \\
\hline \multicolumn{11}{|l|}{ Hippidae } \\
\hline Emerita spp. & 4 & 0 & 0 & 0 & 0 & 0 & 0 & 4 & $<0.1$ & $<1$ \\
\hline Other & 16473 & 5 & 8 & 4 & 0 & 24 & 32 & 16546 & 1.9 & 48 \\
\hline Total & 802818 & 11468 & 6263 & 4506 & 1407 & 15876 & 2964 & 845302 & & \\
\hline$\%$ of total & 95 & 1.4 & 0.7 & 0.5 & 0.2 & 1.9 & 0.4 & & & \\
\hline
\end{tabular}


while dry season precipitation ranged from $0 \mathrm{~mm}$ in February to $40 \mathrm{~mm}$ in April (data from the Instituto Metereologico de Costa Rica).

\section{Species composition}

Both anomuran and brachyuran crabs were included in the analysis, and ca $8.5 \times 10^{5}$ larvae and early juve-

Table 4. Average density (ind. $\mathrm{m}^{-3}$ ) of larval stages of each taxon in Punta Morales, January-December, 1987

\begin{tabular}{lrrrr|}
\hline Taxon & January & May & August & November \\
\hline Ocypodidae & & & & \\
$\quad$ Uca spp. & 8.0 & 229.1 & 284.8 & 66.2 \\
$\quad$ Unidentified & 0.0 & 0.0 & 0.0 & 14.6 \\
Pinnotheridae & & & & \\
$\quad$ Pinnotheres spp. & 6.4 & 25.5 & 26.6 & 26.6 \\
$\quad$ Pinnixa spp. & 5.9 & 1.8 & 3.5 & 1.2 \\
Xanthidae & 25.9 & 28.0 & 40.1 & 29.8 \\
Grapsidae & 2.6 & 40.4 & 124.6 & 22.2 \\
Porcellanidae & & & & \\
$\quad$ Petrolisthes spp. & 7.8 & 7.6 & 9.9 & 5.5 \\
Portunidae & & & & \\
$\quad$ Callinectes spp. & 0.4 & 0.0 & 1.1 & 1.4 \\
Paguridae & 2.8 & 0.7 & 0.7 & 0.8 \\
Leucosiidae & 0.6 & 0.5 & 0.8 & 0.5 \\
Majidae & 0.5 & 0.3 & 0.3 & 0.4 \\
Other & 0.0 & 0.0 & 0.1 & 0.0 \\
Raninidae & 0.4 & 0.2 & 0.1 & 0.0 \\
Hippidae & & & & 0.0 \\
$\quad$ Emerita spp. & 0.0 & 0.4 & 0.0 & 0.0 \\
\hline
\end{tabular}

niles were collected during the study period. These were categorized in 10 families (comprising over $98 \%$ of the total catch) and in a small group of unidentified brachyurans. Definition beyond family was often difficult, but 6 groups were further identified to genus.

Ocypodid larvae (Uca spp.) dominated the samples, comprising $43.0 \%$ of the total catch (Table 3 ). Grapsids ranked second in abundance $(28.7 \%)$, followed by pinnotherids $(13.5 \%)$, xanthids $(9.3 \%)$ and porcellanids $(2.1 \%)$. Leucosiids, majids, raninids, and portunids were collected during most of the year, but were never found in large quantities. Altogether these taxa represented less than $1 \%$ of the total catch.

When tabulated for all taxa, Zoea I were the most abundant stage, representing $95 \%$ of all individuals collected (Table 3). Zoea Stages II to $V$ were 2 orders of magnitude less abundant in most taxa, but the megalopa stage was often more abundant than the intermediate or advanced zoeal stages. Only in Pinnotheres spp. were zoea Stages III to V as abundant as the megalopa.

\section{Seasonal abundance}

Zoeal abundance in 3 families (Leucosidae, Portunidae, and Majidae) was so low that seasonal analysis was not performed. However, the more common taxa showed rather clear patterns of seasonal abundance (Table 4). Analysis of variance showed significant effects of season on abundance of zoea Stage I of ocypodids, grapsids, and Pinnotheres spp. (Table 5). For Uca spp., mean abundance increased from 8.0 zoeae $\mathrm{m}^{-3}$ during January/February (dry season) to

Table 5. Percent of total annual catch of Zoea I and megalopa for each taxon during the study period in Punta Morales, Gulf of Nicoya, Costa Rica

\begin{tabular}{|c|c|c|c|c|c|c|c|c|}
\hline \multirow[t]{2}{*}{ Taxon } & \multicolumn{2}{|c|}{ January } & \multicolumn{2}{|c|}{ May } & \multicolumn{2}{|c|}{ August } & \multicolumn{2}{|c|}{ November } \\
\hline & Z I & Meg. & ZI & Meg. & $\mathrm{ZI}$ & Meg. & Z I & Meg. \\
\hline \multicolumn{9}{|l|}{ Ocypodidae } \\
\hline UCa spp. & 1.0 & 31.0 & 40.0 & 13.0 & 48.0 & 24.0 & 11.0 & 32.0 \\
\hline Grapsidae & 1.0 & 1.0 & 20.0 & 2.0 & 68.0 & 94.0 & 11.0 & 3.0 \\
\hline Xanthidae & 20.0 & 34.0 & 22.0 & 7.0 & 31.0 & 45.0 & 27.0 & 14.0 \\
\hline \multicolumn{9}{|l|}{ Pinnotheridae } \\
\hline Pinnotheres spp. & 5.0 & 78.0 & 32.0 & 14.5 & 23.0 & 3.5 & 40.0 & 4.0 \\
\hline Pinnixa spp. & 55.0 & 97.5 & 13.5 & 2.5 & 17.5 & 0.0 & 14.0 & 0.0 \\
\hline \multicolumn{9}{|l|}{ Porcellanidae } \\
\hline Petrolisthes spp. & 26.0 & 58.0 & 24.0 & 1.0 & 31.0 & 31.0 & 19.0 & 10.0 \\
\hline Majidae & 74.0 & 65.0 & 12.5 & 0.0 & 7.0 & 00 & 6.5 & 35.0 \\
\hline Leucosidae & 46.0 & 0.0 & 18.5 & 0.0 & 8.5 & 0.0 & 17.0 & 0.0 \\
\hline Raninidae & 0.0 & 90.0 & 0.0 & 7.0 & 0.0 & 3.0 & 0.0 & 0.0 \\
\hline \multicolumn{9}{|l|}{ Portunidae } \\
\hline Callinectes spp. & 25.0 & 0.0 & 0.0 & 0.0 & 10.0 & 0.0 & 64.5 & 100.0 \\
\hline
\end{tabular}


more than $200 \mathrm{~m}^{-3}$ as the rainy season began in May. By mid-rainy season (August), mean abundance had risen to nearly $300 \mathrm{~m}^{-3}$. Abundance fell to less than $70 \mathrm{~m}^{-3}$ with the transition to dry season in November. A similar pattern was observed in grapsid crabs with less than 3 zoeae $\mathrm{m}^{-3}$ during dry season and nearly $125 \mathrm{~m}^{-3}$ in mid-rainy season. A slight variation was seen in Pinnotheres spp. where mean densities increased from

Table 6 . Results of 4-way ANOVA comparing the effects of tidal stage, time of day, lunar cycle and time of year on the abundance of larval stages and early juveniles of the various taxa collected during the study period. The analysis was performed on logtransformed densities. E: ebb, F: flood; N: night-time, D: day-time; s: spring tides, $n$ : neap tides; NS: $p>0.05, \cdot p<0.05$. Interactions are indicated with abbreviations corresponding to each factor. $>$ : significantly greater at $\alpha=0.05$. One-way ANOVA was performed for Leucosiidae, Portunidae and Majidae

\begin{tabular}{|c|c|c|c|c|c|c|}
\hline Taxon & Stage & $\begin{array}{l}\text { Tide } \\
\text { (T) }\end{array}$ & $\begin{array}{l}\text { Diel } \\
\text { (D) }\end{array}$ & $\begin{array}{l}\text { Month } \\
\text { (M) }\end{array}$ & $\begin{array}{l}\text { Lunar } \\
\text { (L) }\end{array}$ & Interaction \\
\hline \multicolumn{7}{|l|}{ Ocypodidae } \\
\hline \multirow{6}{*}{ Uca spp. } & I & $E>F$ & NS & • & $s>n$ & $\mathrm{~T} \times \mathrm{L}, \mathrm{D} / \mathrm{M}$ \\
\hline & II & NS & NS & • & $\mathrm{s}>\mathrm{n}$ & $\mathrm{L} \times \mathrm{M}$ \\
\hline & III & NS & $N>D$ & NS & NS & $\mathrm{L} \times \mathrm{M}$ \\
\hline & IV & $F>E$ & NS & $\cdot$ & $n>s$ & $\mathrm{~T} \times \mathrm{L}, \mathrm{D} \times \mathrm{L}$ \\
\hline & $\mathrm{V}$ & $F>E$ & NS & NS & $n>s$ & $\mathrm{~T} \times \mathrm{L}, \overline{\mathrm{D}} \times \mathrm{L}$ \\
\hline & Meg. & $F>E$ & $N>D$ & $\cdot$ & $s>n$ & $\mathrm{~T} \times \mathrm{D}, \mathrm{L} \times \mathrm{M}$ \\
\hline \multirow[t]{5}{*}{ Grapsidae } & I & $E>F$ & $N>D$ & $\cdot$ & $\mathrm{s}>\mathrm{n}$ & $\mathrm{T} \times \mathrm{D}, \mathrm{T} \times \mathrm{L}, \mathrm{L} \times \mathrm{M}$ \\
\hline & II & NS & NS & NS & NS & \\
\hline & III & NS & NS & NS & NS & NS \\
\hline & IV & $F>E$ & NS & NS & NS & NS \\
\hline & Meg. & NS & $N>D$ & $\cdot$ & NS & $\mathrm{D} \times \mathrm{M}, \mathrm{T} \times \mathrm{L}, \mathrm{L} \times \mathrm{M}$ \\
\hline \multicolumn{7}{|l|}{ Pinnotheridae } \\
\hline \multirow[t]{7}{*}{ Pinnotheres spp. } & I & $E>F$ & NS & $\cdot$ & $s>n$ & $L \times M$ \\
\hline & II & NS & $N>D$ & $\cdot$ & $n>5$ & $\mathrm{D} \times \mathrm{M}, \mathrm{D} \times \mathrm{L}, \mathrm{L} \times \mathrm{M}$ \\
\hline & III & NS & $N>D$ & NS & $n>s$ & $\mathrm{D} \times \mathrm{L}$ \\
\hline & IV & $F>E$ & $N>D$ & $\cdot$ & $n>s$ & $\mathrm{D} \times \mathrm{L}$ \\
\hline & $\mathrm{V}$ & $\mathrm{F}>\mathrm{E}$ & $N>D$ & $\cdot$ & NS & NS \\
\hline & Meg. & $F>E$ & $N>D$ & $\cdot$ & $s>n$ & $\mathrm{~T} \times \mathrm{D}, \mathrm{D} \times \mathrm{L}, \mathrm{D} \times \mathrm{M}, \mathrm{L} \times \mathrm{M}$ \\
\hline & Juv. & $F>E$ & $N>D$ & NS & NS & $\mathrm{L} \times \mathrm{M}$ \\
\hline \multirow[t]{7}{*}{ Pinnixa spp. } & I & NS & $D>N$ & $\cdot$ & $n>s$ & $\mathrm{D} \times \mathrm{M}$ \\
\hline & II & NS & NS & NS & $n>s$ & NS \\
\hline & III & NS & NS & NS & NS & $\mathrm{L} \times \mathrm{M}$ \\
\hline & IV & $F>E$ & $N>D$ & NS & NS & $\mathrm{L} \times \mathrm{M}$ \\
\hline & $\mathrm{V}$ & NS & NS & NS & NS & NS \\
\hline & Meg. & $F>E$ & $N>D$ & $\cdot$ & $S>N$ & $\mathrm{D} \times \mathrm{L}, \mathrm{D} \times \mathrm{M}, \mathrm{L} \times \mathrm{M}$ \\
\hline & Juv. & $F>E$ & $N>D$ & $\cdot$ & NS & $\mathrm{T} \times \mathrm{D}, \mathrm{L} \times \mathrm{M}$ \\
\hline \multicolumn{7}{|l|}{ Porcellanidae } \\
\hline \multirow[t]{4}{*}{ Petrolisthes spp. } & I & $E>F$ & $N>D$ & $\cdot$ & $n>s$ & $T \times D$ \\
\hline & II & $F>E$ & $N>D$ & $\cdot$ & NS & $\mathrm{L} \times \mathrm{M}$ \\
\hline & Meg. & $F>E$ & $N>D$ & $\cdot$ & NS & $\mathrm{T} \times \mathrm{D}, \mathrm{D} \times \mathrm{L}, \mathrm{L} \times \mathrm{M}, \mathrm{D} \times \mathrm{M}$ \\
\hline & Juv. & $F>E$ & $N>D$ & $\cdot$ & $s>n$ & $\mathrm{~L} \times \mathrm{M}, \mathrm{D} \times \mathrm{L}$ \\
\hline \multirow[t]{5}{*}{ Xanthidae } & I & $E>F$ & NS & NS & NS & $\mathrm{T} \times \mathrm{D}, \mathrm{L} \times \mathrm{M}$ \\
\hline & II & $F>E$ & NS & $\cdot$ & NS & NS \\
\hline & III & $\mathrm{F}>\mathrm{E}$ & $N>D$ & NS & $n>s$ & $\mathrm{~L} \times \mathrm{M}$ \\
\hline & IV & $F>E$ & NS & NS & $\mathrm{n}>\mathrm{s}$ & $\mathrm{L} \times \mathrm{M}$ \\
\hline & Meg. & $F>E$ & $N>D$ & $\cdot$ & NS & $\mathrm{T} \times \mathrm{D}, \mathrm{L} \times \mathrm{MI}$ \\
\hline \multirow[t]{2}{*}{ Paguridae } & I & NS & NS & NS & NS & NS \\
\hline & Juv. & $F>E$ & $N>D$ & $\cdot$ & & $\begin{array}{l}\mathrm{T} \times \mathrm{D}, \mathrm{T} \times \mathrm{L}, \mathrm{D} \times \mathrm{L} \\
\mathrm{T} \times \mathrm{M}, \mathrm{D} \times \mathrm{M}, \mathrm{L} \times \mathrm{M}\end{array}$ \\
\hline \multirow[t]{3}{*}{ Leucosiidae } & I & NS & NS & NS & NS & \\
\hline & II & NS & NS & NS & NS & \\
\hline & IV & NS & NS & NS & $\cdot$ & \\
\hline \multicolumn{7}{|l|}{ Portunidae } \\
\hline Callinectes spp. & I & NS & NS & $\cdot$ & $s>n$ & \\
\hline Majidae & I & NS & NS & NS & NS & \\
\hline
\end{tabular}


$6 \mathrm{~m}^{-3}$ in mid-dry season to maximum densities of $25 \mathrm{~m}^{-3}$ or more during the rest of the year. In contrast Pinnixa spp. showed maximum abundance in mid-dry season and again in mid-rainy season, with minima during the 2 transition periods.

Analysis of variance showed no significant effect of season on abundance of zoea Stage I in the Xanthidae (Table 6), and the abundance of all stages was relatively high throughout the year.

Megalopae did not show the same pattern of seasonal abundance as zoea Stage I in any of the common taxa (Table 5). For example megalopae of $U_{C a}$ spp. were most abundant during January and November, even though zoea Stage I were much more abundant in May and August. This lack of correspondence suggests that mortality rate for zoeae may vary with season.

\section{Diel and tidal variations in densities}

Zoea Stage I of grapsids, xanthids, ocypodids ( $U_{C a}$ spp.), porcellanids (Petrolisthes spp.), and some pinnotherids (Pinnotheres spp.) were significantly more abundant during ebb than flood tides, suggesting that these larvae were released in the estero and exported to the open gulf (Table 6). In Fig. 2 we show a time series of bihourly abundance of zoea Stage I of Uca spp. as an example of this pattern of abundance.

Later zoeal stages and megalopae of these taxa were more common during flood tides (Table 6). Superimposed on this tidal frequency was a diel and lunar pattern in abundance. Some stages in these taxa were

A

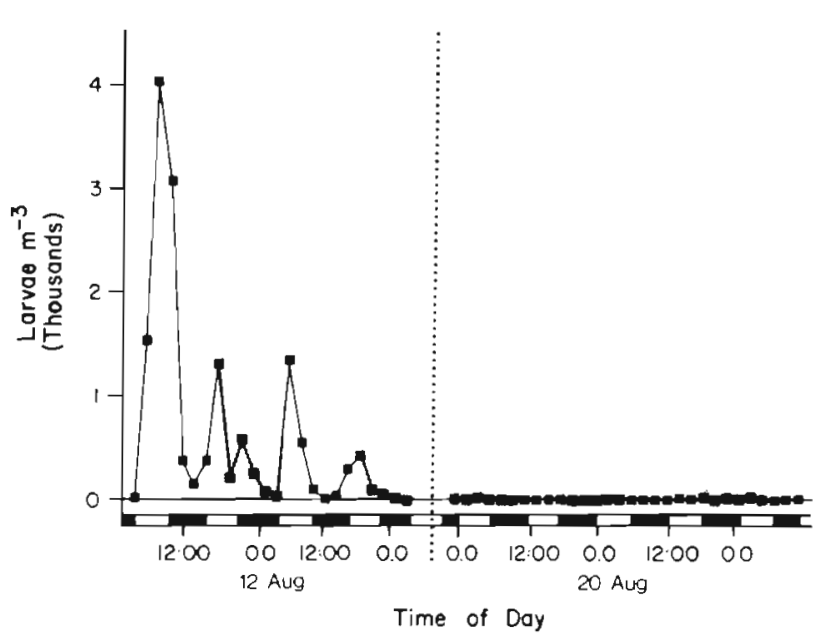

Fig. 2. Uca spp. Bihourly abundance of zoea Stage I in Estero Morales, Costa Rica over 5 consecutive tidal cycles. Dark areas on $\mathrm{X}$-axis indicate flood phase. Light areas on $\mathrm{X}$-axis indicate ebb phase. Shaded areas delineate periods of darkness. This pattern of abundance is typical of species that export zoea Stage I. (A) Spring tide period, 11 to 13 August 1987; (B) neap tide period, 19 to 21 August 1987

significantly more abundant during nocturnal spring tides. In addition, there was a significant interaction between time of day and tidal stage and between time of day and lunar cycle of the megalopal stage. Megalopae in all of these families were significantly more abundant during nocturnal spring floods. In Fig. 3 we show a time series of bihourly abundance of the megalopa stage of $U_{c a}$ spp. as an example of this pattern of abundance.

A

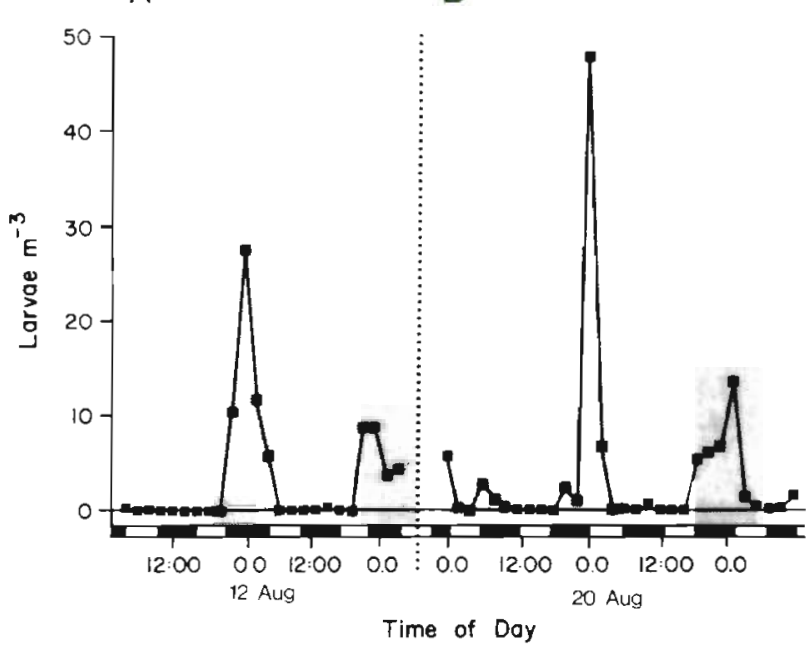

Fig. 3. Uca spp. Bihourly abundance of megalopae in Estero Morales, Costa Rica over 5 consecutive tidal cycles. Dark areas on X-axis indicate flood phase. Light areas on X-axis indicate ebb phase. Shaded areas delineate periods of darkness. This pattern of abundance is typical of species that depend on upstream transport of megalopae for recruitment. (A) Spring tide period, 11 to 13 August 1987; (B) neap tide period, 19 to 21 August 1987

Another pattern of larval abundance was observed in Pinnixa spp. (Pinnotheridae) where there was no significant effect of tidal phase (Table 6). In Fig. 4 we show a time series of bihourly abundance of zoea Stage I of Pinnixa spp. as an example of this pattern.

\section{DISCUSSION}

\section{Composition and seasonal abundance}

While the assemblage of crab larvae observed at Estero Morales showed little taxonomic affinity with assemblages in temperate estuaries further north along the Pacific coast (Gunderson et al. 1990), the relative abundance of common families collected in the estero was strikingly similar to the summer distribution reported in warm temperate estuaries along the Atlantic coast of North America. At Estero Morales, as well as in these Atlantic estuaries, larval collections are dominated by ocypodids ( $U_{c a} \mathrm{spp}$.), pinnotherids, 


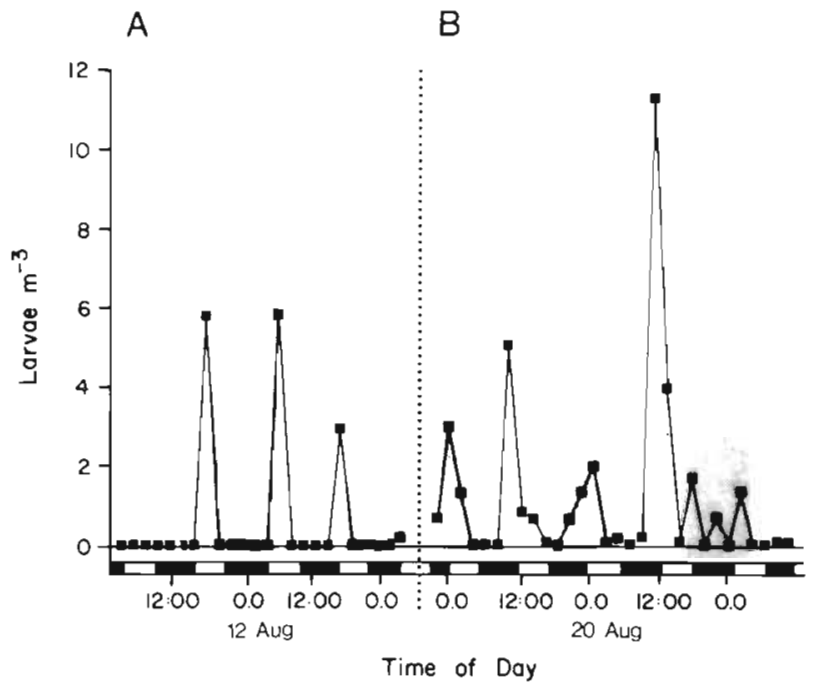

Fig. 4. Pinnixa spp. Bihourly abundance of zoea Stage I in Estero Morales, Costa Rica over 5 consecutive tidal cycles Dark areas on X-axis indicate flood phase. Light areas on Xaxis indicate ebb phase. Shaded areas delineate periods of darkness. This pattern of abundance is typical of species that do not show lunar, tidal, or diel rhythms. (A) Spring tide period, 11 to 13 August 1987; (B) neap tide period, 19 to 21 August 1987

xanthids, and grapsids (Sandifer 1973, 1975, Dittel \& Epifanio 1982, DeLancey 1987). In Estero Morales these families comprised over $97 \%$ of the larvae collected.

Crab larvae were common in Estero Morales throughout the year, but there were distinct seasonal patterns of abundance in the more common taxa. Ocypodids and grapsids showed maximum reproductive activity during the rainy season, while reproduction in xanthids appeared to be continuous throughout the year. However, xanthids were not identified beyond family, so it is possible that individual species may have shown seasonal spawning as well.

The 2 genera of Pinnotheridae collected in the study showed different patterns of seasonal abundance. Most stages of Pinnotheres spp. were significantly more abundant during the rainy season, and in contrast to all other genera, intermediate zoeal stages were relatively common in the estero. The presence of all larval stages, as well as juveniles, in the plankton suggests that Pinnotheres spp. reproduces in this region and that larvae are retained in the system. Similarly, larvae of temperate species of the genera Pinnotheres and Pinnixa have been found predominantly in near-bottom waters (Sandifer 1973, Goy 1976, Dittel \& Epifanio 1982) where non-tidal circulation is upstream thus preventing expulsion from the estuary. Zoeal stages of Pinnixa spp. showed peaks in mid-dry and mid-rainy season, suggesting that more than one species was included in the collections.

In several common taxa there was considerable sea- sonal variation in zoeal abundance, while megalopal abundance remained relatively constant (Table 6). The apparent decoupling of zoeal and megalopal abundance in the common taxa may also be related to our inability to define individual species, but there is also the suggestion of differing zoeal mortality rates in different seasons. These could be caused by seasonal changes in abundance of food and predators or by rainfall-related changes in the circulation of the upper gulf.

Majid, raninid, and leucosiid larvae accurred during most of the year but never in great abundance. This reflects the lack of spawning populations of these families in the upper gulf (Maurer et al. 1984). Portunid zoeae were also rare in Estero Morales in spite of large adult populations of Callinectes arcuatus in the upper gulf (Dittel et al. 1985). This is explained by the fact that $C$. arcuatus migrates to the lower gulf to spawn (DeVries et al. 1983) and that zoea larvae are apparently retained in that area (Epifanio \& Dittel 1984). C. arcuatus megalopae were also rare in Estero Morales, suggesting that metamorphosis occurs in the lower gulf and that recruitment to adult populations is effected by juvenile migration.

\section{Tidal, lunar, and diel variations}

Responses to tidal, lunar, and diel cycles varied both within and among taxa, but 2 general categories emerged. Responses of larvae in the most common taxa fell into the first category where we usually observed a greater abundance of zoea Stage I during ebb than flood tides. This tidal effect was sometimes complicated by significant interactions with either diel or lunar phase, but the overall pattern of abundance suggests that spawning in this group occurred within the estero and that the early zoeae were exported from the estero. Some taxa, e.g. grapsids, Uca spp., and Pinnotheres spp., also showed greater abundance during spring tidal phases. Presumably this would result in augmented exportation, as the tidal prism (intertidal volume) is greater during spring than neap phases.

In this first group, intermediate and advanced zoeal stages, as well as megalopae, were generally more abundant during flood than ebb phases (with the exception of the grapsids). Presumably this resulted in a net import of these stages into the estero. With the megalopae of $U_{c a}$ spp. and Pinnotheres spp., abundance was also greater during spring than neap phases. Again, this would result in augmented transport of the larvae.

Larvae of Pinnixa spp. fell into a second category. Zoeae of Pinnixa spp. were significantly more abundant during daytime and during neap tides, but abun- 
dance of early zoeal stages was not affected by tidal phase. This lack of tidal response by Pinnixa suggests that early zoeae are not exported from the estero. However, the relative abundance of advanced zoeal stages in the estero was no greater for Pinnixa than for the exported species discussed above. Furthermore, Pinnixa megalopae were significantly more abundant during flood tides, suggesting that megalopae are recruited into the estero from the adjacent gulf.

\section{Comparisons with other estuaries}

As in temperate species of $U_{C a}$, zoea Stage I in Estero Morales was more abundant during spring ebb tides, whereas intermediate stages were more abundant during neap flood tides and megalopae during nocturnal spring flood tides. However, no diel pattern of abundance was observed for Uca zoea Stage I. This is in contrast to temperate estuaries where nocturnal hatching has been observed. Nocturnal hatching has been hypothesized to reduce predation on ovigerous adult females (DeCoursey 1979, Seiple 1979) and newly hatched zoeae (Christy 1982). It would appear that this would be selectively advantageous in tropical estuaries as well, so it is not clear why no evidence of the trait was seen in our data.

But overall, the species of Uca in Estero Morales appear to have evolved behavioral adaptations similar to those in temperate forms. These adaptations result in transport of Stage I larvae away from adult habitat and into open water where subsequent zoeal development occurs. Transport of megalopae to adult habitat appears dependent on flood tidal currents.

Just as for temperate grapsid crabs, our results show semilunar and tidal rhythms in the abundance of newly hatched zoeae (Saigusa \& Hidaka 1978, Seiple 1979, Christy \& Stancyk 1982, DeVries \& Forward 1989), but grapsid megalopae appeared more influenced by time of day than by tidal movements. While the nocturnal abundance of grapsid megalopae may be important in avoiding predation, it would appear of little value in upstream transport of the megalopae.

As in temperate estuaries (Cronin \& Forward 1982, Lambert \& Epifanio 1982), xanthid larvae in Estero Morales showed clear tidal rhythms in abundance. Zoeal Stage I larvae were more abundant during ebb tides, while intermediate and advanced zoeae and megalopae were more abundant during flood tides. Other authors have reported an additional lunar rhythm in the abundance of the newly hatched zoeae of intertidal xanthids, but no such rhythm in subtidal species (Christy 1986, Salmon et al. 1986). Because we were unable to identify xanthid larvae beyond the level of family, we would have been unable to distinguish these 2 patterns, even if they existed in Estero Morales.

Our results for porcellanid larvae are consistent with those reported by Christy (1986) for Petrolisthes armatus on the Pacific Coast of Panama. As in the present study, no synchronization of larval release related to lunar phase was observed in $P$. armatus. In contrast to Zoeae I, megalopae of Petrolisthes spp. in Punta Morales appeared to be influenced by tidal, diel and lunar phase. Ontogenetic variations in behavioral responses indicate that selective pressures may differ in the various stages. It is possible that in porcellanid crabs, megalopae require nocturnal flood tides of maximum amplitude to colonize suitable habitats whereas early stages depend on nocturnal ebb tides to be transported seaward.

\section{CONCLUSIONS}

The gross taxonomic composition of the larval assemblage found in Estero Morales was similar to that seen in temperate estuaries along the Atlantic coast of North America. While our taxonomic analysis extended only to the level of genus, results of adult surveys on the Pacific coast of Central America indicate that species richness in Estero Morales exceeds that reported in temperate estuaries (Maurer et al. 1984). Additionally, the abundance of individual taxa was greater than that seen in temperate estuaries with common taxa exceeding 1000 larvae $\mathrm{m}^{-3}$.

In contrast to temperate estuaries, spawning occurred year-round, but individual taxa showed distinct seasonality. As in temperate estuaries, spawning in Estero Morales was also influenced by lunar cycles. In addition, the larvae of several taxa showed tidally rhythmic changes in abundance just as reported for temperate systems. Early stages of many taxa were influenced by tidal movements and lunar cycles that would enable them to be transported seaward whereas later zoeal stages and megalopae appeared to take advantage of nocturnal flood tides to be recruited back in to the estuary. But export of early stages did not occur in all crab taxa, and larvae of Pinnotheres spp. may be retained in the mangrove system throughout zoeal and megalopal development just as they are retained in the upper regions of temperate estuaries (Sandifer 1975).

The similarities between the larval assemblage in Estero Morales and the assemblages in the temperate estuaries along the Atlantic coast of North America are quite remarkable in light of spatial separation by many degrees of latitude and by the Isthmus of Panama. This pattern of similarity goes beyond taxonomic affinity and extends to apparent behavioral responses to lunar. diel, and tidal cycles. This suggests a set of selection factors that transcends latitude, but is common to estuarine environments 
Acknowledgements. The research was supported by NSF Award Number INT-8613439 and by funds from the Universidad de Costa Rica. Facilities in Costa Rica were provided by CONICIT and by the Centro de Investigacion en Ciencias del Mar y Limnologia. We thank lngo Werthmann, Fernando Cabezas and other students from the Universidad de Costa Rica who assisted in field work. Additionally, we want to thank Dr Manuel Murillo for his help and support during the study.

\section{LITERATURE CITED}

Bergin, M. E. (1981). Hatching rhythms in Uca pugilator (Decapoda: Brachyura). Mar. Biol. 63: 151-158

Boicourt, W. C. (1982). Estuarine larval retention mechanisms on two scales. In: Kennedy, V. S. (ed.) Estuarine comparisons. Academic Press, New York, p. 445-457

Bousfield, E. L. (1955). Ecological control of the occurrence of barnacles in the Miramichi estuary. Bull natn. Mus. Can. 137: $1-69$

Carriker, M. R. (1951). Ecological observations on the distribution of oyster larvae in New Jersey estuaries. Ecol Monogr. 21: 19-38

Christy, J. (1978). Adaptive significance of reproductive cycles in the fiddler crabs Uca pugilator: a hypothesis. Science 199: 453-455

Christy, J. (1982). Adaptive significance of semilunar cycles of larval release in fiddler crabs (Uca): a test of an hypothesis. Biol. Bull. mar. biol. Lab., Woods Hole 163: 251-263

Christy, J. (1986). Timing of larval release by intertidal crabs on and exposed shore. Bull. mar. Sci. 39: 176-191

Christy, J., Stancyk, S. E. (1982). Movement of larvae from North Inlet estuary, S. C. with especial reference to crab zoeae. In: Kennedy, V S. (ed.) Estuarine comparisons. Academic Press, New York, p. 489-502

Costlow, J. D. Jr, Bookhout, C. G. (1966). Larval stages of the crab, Pinnotheres maculatus, under laboratory conditions Chesapeake Sci. 7 (3): 157-163

Costlow, J. D. Jr, Fagetti, C. (1967). The larval development of the crab, Cyclograpsus cinereus Dana, under laboratory conditions. Pacif. Sci. 21: 166-177

Cronin, T W. Forward, R. B. (1979). Tidal vertical migration an endogenous rhythm in estuarine crab larvae. Science 205: 1020-1021

Cronin, T W., Forward, R. B. Jr (1982). Tidally timed behavior effects on larval distributions in estuaries. In: Kennedy, V S. (ed.) Estuarine comparisons. Academic Press, New York, p. 505-520

DeCoursey, P. (1979). Egg hatching rhythms in three species of fiddler crabs. In: Naylor, E., Hartnoll, R. (eds.) Cyclic phenomena in marine plants and animals. Pergamon Press, Oxford, p. 399-406

DeCoursey, P. (1981). Cyclic reproduction of fiddler crabs. Uca: a model for estuarine adaptation. Estuaries 4: 263

DeLancey, L. B. (1987). The summer zooplankton of the surf zone at Folly Beach, South Carolina. J. coastal Res. 3 (2): 211-217

De Vries, M. C., Epifanio, C. E., Dittel, A. (1983). Reproductive periodicity of the tropical crab Callinectes arcuatus Ordway in Central America. Estuar. coast. Shelf Sci. 17: $709-716$

De Vries, M. C., Forward, R. B. Jr (1989). Rhythms of larval release of the sublittoral crab Neopanope sayi and the supralittoral crab Sesarma cinereum (Decapoda: Brachyura). Mar. Biol. 100: 241-248

Dittel, A., Epifanio, C. E. (1982). Seasonal abundance and vertical distribution of crab larvae in Delaware Bay. Estuaries 5 (3): 197-202

Dittel, A., Epifanio, C. E., Chavarria, J. B. (1985). Population biology of the portunid crab Callinectes arcuatus Ordway in the Gulf of Nicoya, Costa Rica, Central America. Estuar coast. Shelf Sci. 20: 593-602

Epifanio, C. E. (1988). Dispersal strategies of two species of swimming crab on the continental shelf adjacent to Delaware Bay. Mar Ecol. Prog. Ser. 49: 243-248

Epifanio, C. E., Dittel, A. I. (1984). Seasonal abundance of brachyuran crab larvae in a tropical estuary: Gulf of Nicoya, Costa Rica, Central America. Estuaries 7 (4 B): 501-505

Epifanio, C. E., Masse, A. K., Garvine, R. W. (1989). Transport of blue crab larvae by surface currents off Delaware Bay. USA. Mar. Ecol. Prog. Ser. 54: 35-41

Epifanio, C. E., Maurer, D., Dittel, A. (1983). Seasonal changes in nutrients and dissolved oxygen in the Gulf of Nicoya, a tropical estuary on the Pacific coast of Central America. Hydrobiologia 101: 231-238

Epifanio, C. E., Valenti, C. C., Pembroke, A. E. (1984). Dispersal and recruitment of blue crab larvae in Delaware Bay, USA. Estuar. coast. Shelf Sci. 18: 1-12

Fielder, D. R., Greenwood, J. G. (1986). Zoeal stages of Macrophthalmus setosus $H$. Milne-Edwards, 1852 and $M$. punctulatus Miers, 1884 (Decapoda, Ocypodidae). Mem. Qd. Mus. 22 (2): 155-164

Forward, R. B. Jr (1974). Negative phototaxis in crustacean larvae: possible functional significance. J. exp. mar. Biol. Ecol. 16: 11-17

Goodrich, D. M., van Montfrans, J., Orth, R. J. (1989). Blue crab megalopal influx to Chesapeake Bay: evidence for a wind-driven mechanism. Estuar. coast. Shelf Sci. 29 (3): $247-260$

Gore, R. H. (1972). Petrolisthes armatus (Gibbes, 1850): the development under laboratory conditions of larvae from a Pacific specimen (Decapoda: Porcellanidae). Crustaceana 22 (1): $67-85$

Goy, J. W. (1976). Seasonal distribution and retention of some decapod crustacean larvae within the Chesapeake Bay, Virginia. M. S. thesis, Old Dominion Univ, Norfolk

Gunderson, D., Armstrong, D., Shi, Y., McConnaughey, R. (1990). Patterns of estuarine use by juvenile English sole (Parophrys vetulus) and Dungeness crab (Cancer magister). Estuaries (in press)

Hasmi, S. S. (1968). Study on larvae of (Gelasimus Ocypodidae) reared in the laboratory (Decapoda: Crustacea). Pakist. J. scient. Res. 20 (1-2): 50-56

Hyman, O. W (1920). The development of Gelasimus after hatching. J. Morphol. 33 (2): 485-523

Knight, M. D. (1968). The larval development of Raninoides benedicti Rathbun (Brachyura, Raninidae), with notes on the Pacific records of Raninoides laevis (Latreille). Crustaceana Suppl. II, p. 145-169

Knight-Jones, E. W., Qasim, S. Z. (1966). Response of Crustacea to change in hydrostatis pressure. In: Proc. Symp. Crustacea. Part 3. Marine Biological Association of India, Madras, p. 1132-1150

Lambert, R., Epifanio, C. E. (1982). A comparison of dispersal strategies in two genera of brachyuran crab in a secondary estuary. Estuaries 5: 182-188

Latz, M. I., Forward, R. B. Jr (1977). The effect of salinity upon phototaxis and geotaxis in a larval crustacean. Biol. Bull. mar. biol. Lab., Woods Hole 153: 163-179

Lebour, M. V (1928). Studies of the Plymouth Brachyura. II. The larval stages of Ebalia and Pinnotheres. J. mar. biol. Ass. U. K. 15: 109-123 
Little, K. T., Epifanio, C. E. (1990). Mechanism for the reinvasion of the estuary by two species of brachyuran megalopae. Mar Ecol. Prog. Ser. (in press)

Martin, J. W., Truesdale, F. M., Felder, D. L. (1985). Larval development of Panopeus bermudensis Benedict and Rathbun, 1891 (Brachyura, Xanthidae) with notes on zoeal characters in xanthid crabs. J. crustacean Biol. 5(1): 84-105

Maurer, D., Epifanio, C. E., Dean, H., Howe, S., Vargas, J., Dittel, A., Murillo, M. (1984). Benthic invertebrates of a tropical estuary: Gulf of Nicoya, Costa Rica. J. nat. Hist. 18 : $47-61$

Naylor, E., Isaac, M. J. (1973). Behavioural significance of pressure responses in megalopa larvae of Callinectes sapidus and Macropipus spp. Mar. Behav. Physiol. 1: 341-350

O'Connor, N., Epifanio, C. E. (1985). The effect of salinity on the dispersal and recruitment of fiddler crab larvae. J. crustacean Biol. 5 (1): 137-145

Ott, F. S., Forward, R. B. Jr (1976). The effect of temperature on phototaxis and geotaxis by crab larvae of the crab Rhithropanopeus harrisii. J. exp. mar. Biol. Ecol. 23 97-107

Paula, J. (1989). Rhythms of larval release of decapod crustaceans in the Mira Estuary, Portugal. Mar. Biol. 100 309-312

Robertson, A. I., Dixon, P., Daniel, P. A. (1988). Zooplankton dynamics in mangrove and other nearshore habitats in tropical Australia. Mar. Ecol. Prog. Ser. 43: 139-150

Saigusa, M. (1981). Adaptive significance of semilunar rhythm in the terrestrial crab Sesarma. Biol. Bull. mar. biol. Lab. Woods Hole 160: 311-321

Saigusa, M., Hidaka, T. (1978). Semilunar rhythm in the zoearelease activity of the land crabs Sesarma. Oecologia (Berl.) 37: 163-176

Salmon, M., Seiple, W. H., Morgan, S. G. (1986). Hatching rhythms of fiddler crabs and associated species at Beaufort, North Carolina, J. crustacean Biol. 6: 24-37

Sandifer, P. A. (1972). Morphology and ecology of Chesapeake Bay decapod crustacean larvae. Ph. D. dissertation, University of Virginia, Charlottesville

Sandifer, P. A. (1973). Distribution of decapod crustacean larvae in the York River and Adjacent Lower Chesapeake Bay, Virginia 1968-1969. Chesapeake Sci. 14, 235-257

Sandifer, P. A. (1975). The role of pelagic larvae in recruitment

This article was submitted to the editor to populations of adult decapod crustaceans in the York River Estuary and Adjacent Lower Chesapeake Bay, Virginia. Estuar coast. mar. Sci. 3: 269-279

Seiple, W. (1979) Distribution, habitat preferences and breeding periods in the crustaceans Sesarma cinereum and $S$. reticulatum (Brachyura: Decapoda: Grapsidae). Mar. Biol. 52: $77-86$

Seliger, H. H., Boggs, J. A., Rivkin, R. B., Biggley, W. H., Aspden, K. R. H. (1982). The transport of oyster larvae in an estuary. Mar. Biol. 71: 57-72

Sulkin, S. (1973). Depth regulation of crab larvae in the absence of light. J. exp. mar. Biol. Ecol. 13: 73-82

Sulkin, S. (1975). The influence of light in the depth regulation of crab larvae. Biol. Bull. mar. biol. Lab., Woods Hole 148: 333-343

Sulkin, S., van Heukelem, W. (1982). Larval recruitment in the crab Callinectes sapidus Rathbun: an amendment to the concept of larval retention in estuaries. In: Kennedy, $\mathrm{V}$ S. (ed.) Estuarine comparisons. Academic Press, New York, p. $459-475$

Sulkin, S., van Heukelem, W., Kelly, P., van Heukelem, L. (1980). The behavioral basis of larval recruitment in the crab Callinectes sapidus Rathbun: a laboratory investigation of ontogenetic changes in geotaxis and barokinesis. Biol. Bull. mar biol. Lab., Woods Hole 159: 402-417

Vargas, J. A. (1987). The benthic community of an intertidal mud flat in the Gulf of Nicoya, Costa Rica. Revta Biol. trop. 35: 299-316

Voorhis, A. D., Epifanio, C. E., Maurer, D., Dittel, A. I, Vargas, J. (1983). The estuarine character of the Gulf of Nicoya, an embayment on the Pacific coast of Central America. Hydrobiologia 99: 225-237

Wheeler, D. E., Epifanio, C. E. (1978). Behavioral response to hydrostatic pressure in larvae of two species of Xanthid crabs. Mar. Biol. 46: 167-174

Wood, L., Hargis, W. Jr (1971). Transport of bivalve larvae in a tidal estuary. In: Crisp, D. J. (ed.) Proc. 4th Eur. Mar. Biol. Symp. Cambridge Univ. Press, London, p. 29-44

Youngbluth, M. J. (1980). Daily, seasonal and annual fluctuations among zooplankton populations in an unpolluted tropical embayment. Estuar coast. Shelf Sci. 10: 265-287

Zucker, N. (1978). Monthly reproductive cycles in three sympatric hood-building tropical fiddler crabs (Genus Uca). Biol. Bull. mar. biol. Lab., Woods Hole 155: 410-424

Manuscript first received: December 6, 1989

Revised version accepted: March 16, 1990 